\title{
Venus Khoury-Ghata, Sept pierres pour la femme adultère
}

Veronica Amadessi

\section{(2) OpenEdition}

\section{Journals}

Édition électronique

URL : http://journals.openedition.org/studifrancesi/9068

DOI : 10.4000/studifrancesi.9068

ISSN : 2427-5856

Éditeur

Rosenberg \& Sellier

\section{Édition imprimée}

Date de publication : 1 octobre 2008

Pagination : 501

ISSN : 0039-2944

\section{Référence électronique}

Veronica Amadessi, « Venus Khoury-Ghata, Sept pierres pour la femme adultère », Studi Francesi [En ligne], 155 (LII | II) | 2008, mis en ligne le 30 novembre 2015, consulté le 09 janvier 2021. URL : http:// journals.openedition.org/studifrancesi/9068; DOI : https://doi.org/10.4000/studifrancesi.9068

Ce document a été généré automatiquement le 9 janvier 2021.

\section{(c) (†) $\odot$}

Studi Francesi è distribuita con Licenza Creative Commons Attribuzione - Non commerciale - Non opere derivate 4.0 Internazionale. 
Venus Khoury-Ghata, Sept pierres

pour la femme adultère

Veronica Amadessi 


\section{RÉFÉRENCE}

VENUS KHOURY-GHATA, Sept pierres pour la femme adultère, Paris, Mercure de France, 2007, pp. 188.

1 Vénus Khoury-Ghata fascine son lecteur avec ce nouveau roman, qui ressemble à un récit fantastique mais qui dénonce cependant la terrible réalité féminine dans certaines sociétés. L'histoire se déroule dans un village musulman aux confins du désert, où une jeune française se rend en mission humanitaire. Sa tâche principale étant de s'occuper de Noor, une femme condamnée à la lapidation, la jeune européenne rentre petit à petit dans un monde très différent du sien, où les valeurs, les préjugés, les modes de vie semblent être complètement renversés. à côté de Noor et de la femme de ménage du centre médical, Amina, elle explore un univers encore fermé au bien-être et à l'égalité des hommes et des femmes. Univers terrible, où une fatwa pour adultère pèse sur une femme violée, et où cette femme accepte la volonté du juge qui l'accuse injustement. Les voix féminines se croisent dans la narration et créent ainsi un jeu de mise en perspective des faits qui ont lieu dans le village. Les valeurs n'étant pas les mêmes, ce qui apparaît comme un problème à la jeune française ne l'est pas forcément pour Noor, et vice-versa. La polyphonie du discours narratif agit ici comme un tableau de Picasso: tous les éléments sont donnés et montrés en même temps, en dépit des règles de la perspective. Chaque narratrice, tout en assumant son rôle, ne reste cependant pas forcément ancrée dans sa vision des choses, qui peut changer grâce à un rêve ou à la folie: en effet, la folie vient à la surface et se heurte à l'espoir et à l'envie de changement. Avec ce roman, tableau émouvant de la difficulté de vivre dans une société fermée, l'écrivaine libanaise nous charme une fois de plus grâce à ses portraits exacts et à sa brillante capacité de raconter. 